\title{
Application of different thermal analysis techniques for the evaluation of petroleum source rocks
}

\author{
Małgorzata Labus ${ }^{1}$ (D) $\cdot$ Irena Matyasik ${ }^{2}$
}

Received: 19 March 2018/Accepted: 15 September 2018/Published online: 25 September 2018

(c) The Author(s) 2018

\begin{abstract}
In the paper, various laboratory pyrolytic methods were used to evaluate selected petroleum source rocks. The methods used are: Rock-Eval pyrolysis, Py-GC pyrolytic technique and TG/DTG/DSC. The experiments of the last method were performed according to three different procedures. Each of them provided different, specific data. The selected rock sample material was diversified in terms of stratigraphical position, structural unit and place of collection (outcrop or borehole). Based on the Rock-Eval analysis results, kerogen in samples can be classified as type II. Additional information on the quality of pyrolysis products was obtained from the Py-GC analysis. Thanks to the combination of the all three implemented pyrolytic techniques, the quality of the generation potential of the source rocks can be evaluated in details. In some samples, the oxidation and pyrolysis of organic matter occur in two stages, what is the evidence of the complex nature of the organic substance. The maximum of pyrolysis reaction is detected by TG/DTG measurement in the range of temperature from 450 to $580{ }^{\circ} \mathrm{C}$, depending on the maturity of organic matter. The maturity level increases with the rock stratigraphic position. The proportions of loss in mass observed in respective stages of pyrolysis in course of TG/DTG experiment are in correspondence with the observations of the released fractions in the Py-GC analysis. The Carpathian Menilite shales could be classified as source rocks with high oil generation potential. Also, the Lower Silurian and Ordovician shales are characterized by high oil-producing potential with a lower content of mineral matter. Cambrian rocks show a different character and gas-prone generation potential.
\end{abstract}

Keywords Generation potential $\cdot$ Kerogen $\cdot$ Pyrolysis · Rock-Eval · TG/DSC · Py-GC

\section{Introduction}

Source rock is one of the main elements of petroleum system. Therefore, to estimate the petroleum resources, it is necessary to investigate the source rock and its characteristics first. In order to evaluate the source rocks, various laboratory methods are used. Among these techniques, Rock-Eval pyrolysis has been widely used in the industry, as a standard method in petroleum exploration.

The nature of organic matter, dispersed within finegrained rocks, is related to both the age of the strata and

Małgorzata Labus

malgorzata.labus@polsl.pl

1 Institute for Applied Geology, Silesian University of Technology, 2 Akademicka St., 44-100 Gliwice, Poland

2 Oil and Gas Institute - National Research Institute, 25A Lubicz St., 31-503 Kraków, Poland depositional environment conditions, as well as subsequent diagenetic processes. All of these factors determine the generation potential to hydrocarbons. The aim of the research was detailed characteristic of the examined rocks, regarding their thermal decomposition, which could inform about the generation potential depending on the temperature and energy release. It is assumed that the total loss of mass of the sample during its heating in the range corresponding to the decomposition of organic matter is closely related to the presence of hydrocarbons in the rock, and the value of the maximum temperature of decomposition depends on the maturity of organic matter.

The Rock-Eval pyrolysis is the most basic method of organic geochemical analysis of sediments. It is based on a steady heating of rock samples to release hydrocarbons which had been already generated in the formation and are stored in pores of the rock, as well as newly produced hydrocarbons by the thermal breakdown of kerogen. The 
hydrocarbons already present in the sample are represented by indicator $S_{1}$, while those produced during pyrolysis by indicator $S_{2}$. The relative amounts of $S_{1}$ and $S_{2}$ are dependent on the type of organic matter and on the thermal energy (time and temperature); the rock has already gone through in the subsurface [1]. The temperature corresponding to the maximum production of hydrocarbons during pyrolysis of the kerogen $\left(T_{\max }\right)$ gives an indication of maturity of the studied organic matter. In general, $T_{\max }$ values lower than $435{ }^{\circ} \mathrm{C}$ indicate immature organic matter. $T_{\max }$ values between 435 and $455^{\circ} \mathrm{C}$ indicate "oil window" conditions (mature organic matter). Values between 455 and $470{ }^{\circ} \mathrm{C}$ are considered transitional. $T_{\max }$ higher than $470{ }^{\circ} \mathrm{C}$ represents the wet-gas zone and overmature organic matter $[2,3]$.

Py-GC system is an additional pyrolytic technique for the rapid evaluation of potential source rocks. It was used in presented work for determination of hydrocarbon production by gas chromatographic (GC) analysis of the thermal extracts and pyrolysis products of rock samples. The product type is recognized qualitatively by GC fingerprint traces or quantitatively by hydrocarbon composition $\left(\mathrm{C}_{1}\right.$ to $\mathrm{C}_{9}, \mathrm{C}_{9}$ to $\left.\mathrm{C}_{15}, \mathrm{C}_{15+}\right)$ from the rock pyrolysate. Oil-prone rocks are recognized by $\mathrm{GC}$ traces with a full spectrum of $\mathrm{C}_{1}$ to $\mathrm{C}_{28}$ hydrocarbons, or by high concentrations of $\mathrm{C}_{15+}$ compounds. In contrast, gas-prone kerogens are characterized by the predominance of light hydrocarbons from $C_{1}$ to $C_{4}$ and higher contributions of aromatic compounds. Mixed-type production is intermediate in character between the two mentioned.

Thermogravimetric (TG) and differential scanning calorimetry (DSC) methods are a powerful group of analytical methods, providing additional information on the mineral and organic matter content in the sample. The shapes and peaks of curves obtained from thermal analysis are indicators of the composition and structure of the organic matter in the sample. The temperature range over which the reactions take place is a function of the bonding energies of the various functional groups or other structural elements within the matrix [4]. The application of TG/DTA methods in air atmosphere to study organic matter in sedimentary rocks was developed extensively in the 1970's. In the next decades, thermal analysis was broadly used for the investigation of petroleum products [5], as well as coal and organic matter contained rocks [6]. Also DSC technique was used for organic matter recognition in oil shales or kerogen evaluation in source rocks [6-10]. In most cases, the kerogen is separated from the rock [11], but some attempts to examine bulk rock were also undertaken $[12,13]$.

The vast majority of up-to-date research was focused on oil shale $[11,14]$, while relatively little research was concerned on gas shale and hydrocarbon source rocks [13].
Petroleum source rock is fine-grained sediment, containing organic matter, commonly shales or lime mudstones. The main analytical problem is organic matter dispersion within the rock matrix, which, on the one hand, makes it difficult to examine the organics; on the other hand, it requires the consideration of the mineral components of the rock, as they have a significant influence on the kerogen decomposition.

In this paper, some attempts were made to correlate the results obtained from the Rock-Eval pyrolysis, Py-GC pyrolytic technique and TG/DSC for complete characterisation of fine-grained rocks containing organic matter. Due to the fact that we had a diversified research material- the samples varies in terms of stratigraphy, structural unit and place of collection (outcrop or borehole sample) - it is possible to compare the results obtained in the aspect of all these factors.

\section{Samples and methods}

The examined 11 rock samples represent shales and mudstones from outcrops or deep holes from different geological regions of Poland. Within Lower Paleozoic rocks from deep holes, located in Baltic Syneclise in Poland, samples 10 and 11 are Upper Cambrian shales, samples 8 and 9 are from Upper Ordovician Sasino Formation, samples 6 and 7 represent Lower Silurian Jantar Member, sample 5 is Upper Silurian shale. Samples 1-4 were taken from the outcrops and represent Carpathian Krosno Beds and Menilite Beds of Silesia and Magura units (Table 1).

The Rock-Eval analysis was performed in Oil and Gas Institute-National Research Institute (O\&GI-NRI), with the Rock-Eval-6 standard model on whole-rock samples, which were grinded in agate mortar to $<0.02 \mathrm{~mm}$ grain size. At the first stage, the pyrolysis was run under inert (nitrogen) atmosphere in temperature range from 300 to $650{ }^{\circ} \mathrm{C}$, at $25^{\circ} \mathrm{C} \mathrm{min}^{-1}$, to release kerogen-bound hydrocarbons, and oxygen-containing compounds. At the next stage, the sample was combusted in oxidation atmosphere, at $20{ }^{\circ} \mathrm{C} \mathrm{min}{ }^{-1}$, from 300 to $850{ }^{\circ} \mathrm{C}$. The released combustion products $\left(\mathrm{CO}_{2}\right.$ and $\left.\mathrm{CO}\right)$ were analysed by $\mathrm{IR}$ detector.

Additionally, the new research method was used, which was pyrolysis gas chromatography (Py-GC), applied to determine organic compounds generated by rocks. The apparatus used was Multi-Shot Pyrolizer EGA/PY-3030D by Frontier Laboratories, coupled with gas chromatograph GC-2010 Plus by Shimadzu, equipped with flame ionization detector (FID). Py-GC analyses were performed in Oil and Gas Institute-National Research Institute (O\&GINRI) in Cracow (Poland). In the system, before entering the chromatographic column, a cryogenic trap, cooled with 
Table 1 Rock-Eval pyrolysis results

\begin{tabular}{|c|c|c|c|c|c|c|c|c|c|c|c|c|}
\hline Sample & Lithostratigraphy & $\mathrm{T}_{\max }$ & $S_{1}$ & $S_{2}$ & $S_{3}$ & PI & $\mathrm{PC}$ & $\mathrm{RC}$ & TOC & $\mathrm{HI}$ & OI & MINC \\
\hline 1 & Krosno Beds, Silesian unit & 422 & 0.22 & 16.97 & 6.53 & 0.01 & 1.74 & 5.17 & 6.91 & 246 & 95 & 0.25 \\
\hline 2 & Menilite beds, Silesian unit & 421 & 0.14 & 12.00 & 0.64 & 0.01 & 1.07 & 3.02 & 4.09 & 293 & 16 & 1.43 \\
\hline 3 & & 417 & 0.20 & 20.24 & 0.75 & 0.01 & 1.77 & 3.57 & 5.34 & 379 & 14 & 1.55 \\
\hline 4 & Menilite Beds, Magura unit & 424 & 0.29 & 23.29 & 0.43 & 0.01 & 2.03 & 4.87 & 6.90 & 338 & 6 & 2.55 \\
\hline 5 & Upper Silurian & 430 & 0.25 & 0.13 & 0.44 & 0.66 & 0.05 & 0.11 & 0.16 & 81 & 275 & 1.21 \\
\hline 6 & Lower Silurian shale & 442 & 2.31 & 18.62 & 0.42 & 0.11 & 1.76 & 3.80 & 5.56 & 335 & 8 & 0.41 \\
\hline 7 & Lower Silurian shale & 454 & 2.20 & 9.13 & 0.25 & 0.19 & 0.95 & 5.36 & 6.31 & 145 & 4 & 0.44 \\
\hline 8 & Ordovician shale & 444 & 2.20 & 9.92 & 0.44 & 0.18 & 1.03 & 1.96 & 2.99 & 332 & 15 & 0.43 \\
\hline 9 & Ordovician shale & 451 & 2.40 & 7.88 & 0.02 & 0.23 & 0.87 & 4.08 & 4.95 & 159 & 0 & 0.39 \\
\hline 10 & Upper Cambrian shale & 432 & 2.15 & 19.69 & 0.40 & 0.10 & 1.85 & 9.18 & 11.03 & 179 & 4 & 0.43 \\
\hline 11 & Upper Cambrian shale & 443 & 1.44 & 5.68 & 0.09 & 0.20 & 0.61 & 7.77 & 8.38 & 68 & 1 & 0.18 \\
\hline
\end{tabular}

$T_{\max }$ - the temperature at which the maximum amount of organic hydrocarbons is generated $/{ }^{\circ} \mathrm{C} ; S_{1}$-the quantity of free hydrocarbons at moderate temperature $\left(300^{\circ} \mathrm{C}\right) / \mathrm{mg} \mathrm{HC} \mathrm{g}^{-1}$ rock; $S_{2}$-hydrocarbons generated by the pyrolytic degradation of the heavy products and kerogen $\left(300-650{ }^{\circ} \mathrm{C}\right) / \mathrm{mg} \mathrm{HC} \mathrm{g}^{-1}$ rock; $S_{3}$ - the quantity of $\mathrm{CO}_{2}$ produced during pyrolysis $/ \mathrm{mg} \mathrm{CO}_{2} \mathrm{~g}^{-1}$ rock; PI $=S_{1} /\left(S_{1}+S_{2}\right)$ - generation index; $\mathrm{PC}$ - pyrolytic carbon content/mass\%; RC-residual carbon content/mass\%; TOC—-total organic carbon/mass\%; HI—hydrogen index/mg HC $\mathrm{g}^{-1}$ TOC; OI—oxygen index/mg $\mathrm{CO}_{2} \mathrm{~g}^{-1} \mathrm{TOC} ; \mathrm{MINC}$-mineral inorganic carbon/mass\%

liquid nitrogen, is installed, due to the combination of the MicroJet Cryo-Trap MJT-1030Ex trap. The amount of sample depends on its type and should be adjusted to the technical parameters of chromatography column, detector and pyrolyser. The pyrolysis process is the most effective when using small amounts of sample. In the case of analyses of organic matter-rich material (e.g. bituminous extract, asphaltene fraction), the amounts of the sample should range from 0.1 to $1.0 \mathrm{mg}$; in the case of kerogen its quantity should be up to $3 \mathrm{mg}$, while the amount of rock samples should be about $10 \mathrm{mg}$. Sample is pyrolysed in pyrolysis oven under helium atmosphere at programmed temperature (e.g. $650{ }^{\circ} \mathrm{C}$ during $0.4 \mathrm{~min}$ ). Products of thermal decomposition of analysed sample are collected in cryogenic trap, next send to gas chromatography column and analysed using FID detector. Cryogenic trap and gas chromatography column are connected by dispenser, which temperature is $250{ }^{\circ} \mathrm{C}$.

The parameters of chromatography analysis are as follows: capillary column Ultra Alloy-5 of $30.0 \mathrm{~m}$ length, $0.25 \mathrm{~mm}$ inner diameter, $025 \mu \mathrm{m}$ film thickness, carrier gas (helium) of constant flow speed $1.98 \mathrm{~mL} \mathrm{~min}{ }^{-1}$, temperature of FID detector: $360{ }^{\circ} \mathrm{C}$, temperature programme: $30{ }^{\circ} \mathrm{C}-5 \mathrm{~min}$, temperature gradient $10{ }^{\circ} \mathrm{C} \mathrm{min}^{-1}$ to $360{ }^{\circ} \mathrm{C}$, and isothermal stage at $360{ }^{\circ} \mathrm{C}-10 \mathrm{~min}$, split 10:1.

The thermal analysis was performed in Laboratory of Geochemical Engineering in Silesian University of Technology (Gliwice, Poland) with use of TG and DSC thermal methods on the NETZSCH STA 449 F3 Jupiter ${ }^{\circledR}$ equipment. The samples were powdered and put into the alumina $\left(\mathrm{Al}_{2} \mathrm{O}_{3}\right)$ crucible in amount of about $20 \mathrm{mg}$. The analysis of the rock samples was carried out under the oxidising atmosphere (synthetic air) and under inert gas (nitrogen), with gas flow rate of $50 \mathrm{~mL} \mathrm{~min}{ }^{-1}$. The measurements were taken according to three different experiment procedures:

Procedure I Heating with constant rate of $10{ }^{\circ} \mathrm{C} \mathrm{min}^{-1}$ in the temperature range of $40-1050{ }^{\circ} \mathrm{C}$ under oxidising atmosphere.

Procedure II Heating with constant rate of $10{ }^{\circ} \mathrm{C} \mathrm{min}^{-1}$ in the temperature range of $40-1050{ }^{\circ} \mathrm{C}$ under inert atmosphere.

Procedure III Complex heating programme, close to the Rock-Eval pyrolysis analysis (under inert atmosphere), composed of 5 stages:

1. Heating from 40 to $300{ }^{\circ} \mathrm{C}\left(10{ }^{\circ} \mathrm{C} \mathrm{min}-1\right)$,

2. Isothermal stage on the constant temperature of $300{ }^{\circ} \mathrm{C}(20 \mathrm{~min})$.

3. Heating from 300 to $650{ }^{\circ} \mathrm{C}\left(10^{\circ} \mathrm{C} \mathrm{min}{ }^{-1}\right)$,

4. Isothermal stage on the constant temperature of $650{ }^{\circ} \mathrm{C}(20 \mathrm{~min})$.

5. Heating up to $1050{ }^{\circ} \mathrm{C}\left(10^{\circ} \mathrm{C} \min ^{-1}\right)$.

\section{Measurement results}

\section{Rock-Eval pyrolysis}

The results of Rock-Eval analysis are presented in Table 1 . The first four samples (1-4) represent shales from Carpathian outcrops which are characterized by low maturity. Free hydrocarbons content indicated by value $S_{1}$ varies 
from 0.14 to $0.29 \mathrm{mg} \mathrm{HC} \mathrm{g}^{-1}$ rock. Hydrocarbon-generating potential $\left(S_{2}\right)$ for these samples varies from 12.0 to $23.29 \mathrm{mg} \mathrm{HC} \mathrm{g}^{-1}$ rock. $S_{2}$ peak is a result of the second stage of pyrolysis, when cracking of the kerogen and heavy hydrocarbons occurs. The amount of organic matter, expressed by the TOC value, ranges from 4.09 to 6.91 . The amount of inorganic carbon (MINC) in Carpathian immature shales samples ranges from 0.25 to $2.55 \%$. The ratio of HI values (hydrogen index) to $T_{\max }$ indicates that most of the Carpathian samples contain oil-prone type II kerogen.

The next set of the samples were taken from the bore holes and represent dark and grey shales of lower Paleozoic sequences. They stand out for their high-level maturity. That means that part of primary hydrocarbon potential was evolved. $S_{2}$ represents residual hydrocarbon-generating potential for these samples and varies from 5.68 to $19.69 \mathrm{mg} \mathrm{HC} \mathrm{g}^{-1}$ rock. This parameter indicates that these samples are also very good source rocks. One of the samples out of Paleozoic rocks (Upper Silurian sample 5) differs from the others by very low content of TOC and lack of generating potential. In case of very low organic matter contents, when $S_{2}$ value is lower than $2 \mathrm{mg} \mathrm{HC} \mathrm{g}^{-1}$ rock, this peak is too low for a substantial evaluation of the $T_{\max }[15]$.

Not taking into account the mentioned sample 5, we can state that all the examined rocks from outcrops are thermally immature $\left(T_{\max }<435^{\circ} \mathrm{C}\right)$, whereas Paleozoic samples, mainly $6,7,9$ and 11 , seem to be thermally mature $\left(T_{\max }\right.$ in the range between 435 and $\left.455{ }^{\circ} \mathrm{C}\right)$.

\section{TG/DTG/DSC experiments}

The results of TG/DSC analysis are given in a graphical form as plots of TG and DSC curves in a function of temperature or time. Below are presented plots for sample 2, as an example. The results obtained for all examined samples in Procedures I and II are given in Table 2. The temperature range for each of the reaction is given, and in most cases, based on DTG curves, the temperature of maximum reaction rate is in brackets. Most of the reactions are connected to the mass loss, which is determined on TG curves. The results of TG/DSC analysis were interpreted based on Földvári [16] and Yariv [17].

\section{Procedure I}

All the samples were analysed under dynamic oxidising (synthetic air) atmosphere in the temperature range of ${ }^{40-1050}{ }^{\circ} \mathrm{C}$. The simultaneous thermal analysis enables obtaining of TG and DSC curves on the common diagram (Fig. 1). TG curve shows the change in mass of a material as a function of time over a temperature range. DTG is a first derivative of TG, providing the rate of mass change.
DSC measures the difference in energy input required to maintain the sample and reference cells at the same temperature. The DSC curve shows the amount of heat applied, as a function of temperature or time.

The example of the result of the measurement in Procedure $\mathrm{I}$ is shown in Fig. 1. The mass loss on TG curve is of three steps in case of sample 2. The first step, between 40 and $237^{\circ} \mathrm{C}$, is due to clay minerals dehydration. The maximum of the reaction falls on $107^{\circ} \mathrm{C}$, which is indicated in DTG curve. The mass loss connected with this reaction is $2.57 \%$ of the sample mass. The second reaction is exothermal, what is visible as positive double peak on DSC curve. Hence, we can see that the organic matter combustion occurs in two stages between 237 and $625{ }^{\circ} \mathrm{C}$ (maxima: $344,437^{\circ} \mathrm{C}$ ), with total mass loss of $10.32 \%$. The next reaction is endothermic (negative peak on DSC curve), related to carbonate $\left(\mathrm{CaCO}_{3}\right)$ decomposition. The mass loss results from the release of $\mathrm{CO}_{2}$ into the atmosphere and is $4.65 \%$. The maximum of this reaction is visible in DTG curve, and it falls on $756^{\circ} \mathrm{C}$. In temperature of $923{ }^{\circ} \mathrm{C}$ on DSC curve is noticeable an exothermic effect, not connected to the mass change in the sample. This indicates spinel phases synthesis, as a consequence of clay minerals decomposition.

All of the observed reactions in the examined samples are presented in Table 2. The detected phases include clay minerals (including chlorites), micas (muscovite), carbonates (calcite) and organic matter. Some problem with interpretation of curves is the separation of the organic matter combustion and the decomposition of pyrite, which is present in some organic-rich rocks. This problem could be solved to some extend with help of TG/DTG/DSC experiment under inert atmosphere [12].

\section{Procedure II}

In the second procedure of TG/DTG/DSC experiment, the samples were heated with constant rate of $10{ }^{\circ} \mathrm{C} \mathrm{min}-1$ under inert atmosphere. In this case the organic matter dispersed in rock is not combusted, but pyrolysed instead. The results (Fig. 2) are shown on the example of the same sample (2) as before (Fig. 1).

The first reaction visible in the graph is clay minerals dehydration, with maximum falling on $116{ }^{\circ} \mathrm{C}$, which is indicated in DTG curve. The second reaction is endothermic, what is visible as a weak negative (downwards) peak on DSC curve. This effect corresponds to the double peak on the DTG curve, indicating that the pyrolysis proceeds in two steps. Total mass loss of pyrolysis reaction is $7.76 \%$. The next reaction is endothermic (negative peak on DSC curve), related to calcite decomposition. The maximum of the reaction rate falls on $759{ }^{\circ} \mathrm{C}$. When comparing with the mass loss of calcite decomposition in case of the Procedure 
Table 2 TG/DSC results for the examined rocks

\begin{tabular}{|c|c|c|c|c|c|c|}
\hline \multirow[t]{2}{*}{ Sample } & \multicolumn{3}{|l|}{$\begin{array}{l}\text { Procedure I } \\
\text { Oxidising atmosphere }\end{array}$} & \multicolumn{3}{|l|}{$\begin{array}{l}\text { Procedure II } \\
\text { Inert atmosphere }\end{array}$} \\
\hline & Reaction & $\begin{array}{l}\text { Temperature range/ } \\
{ }^{\circ} \mathrm{C}\end{array}$ & $\begin{array}{l}\text { Mass } \\
\text { loss } / \%\end{array}$ & Reaction & $\begin{array}{l}\text { Temperature } \\
\text { range } /{ }^{\circ} \mathrm{C}\end{array}$ & $\begin{array}{l}\text { Mass } \\
\text { loss } / \%\end{array}$ \\
\hline \multirow[t]{5}{*}{1} & 1. Clay minerals dehydration & $40-/ 100 /-223$ & 5.68 & 1. Clay minerals dehydration & $50-/ 123 /-204$ & 1.39 \\
\hline & 2. Organic matter combustion & $223-/ 325,382 /-460$ & 9.00 & 2. Chlorite dehydration & 204-282 & 0.50 \\
\hline & \multirow{3}{*}{$\begin{array}{l}\text { 3. Clay minerals and chlorite } \\
\text { dehydroxylation }\end{array}$} & \multirow[t]{3}{*}{$460-/ 511 /-587$} & \multirow[t]{3}{*}{3.19} & 3. Pyrolysis stage I & $282-/ 453 /-483$ & 4.36 \\
\hline & & & & 4. Pyrolysis stage II & $483-/ 506 /-643$ & 2.94 \\
\hline & & & & 5. Chlorite dehydroxylation & $643-/ 774 /-850$ & 2.02 \\
\hline \multirow[t]{4}{*}{2} & 1. Clay minerals dehydration & $40-/ 107 /-237$ & 2.57 & 1. Clay minerals dehydration & $40-/ 116 /-215$ & 1.51 \\
\hline & 2. Organic matter combustion & $237-/ 437 /-625$ & 10.32 & 2. Pyrolysis stage I & $370-485$ & 2.59 \\
\hline & 3. Calcite decomposition & $625-/ 756 /-870$ & 4.65 & 3. Pyrolysis stage II & $485-/ 525 /-640$ & 5.17 \\
\hline & 4. Spinel phases crystallisation & Max. 923 & - & 4. Calcite decomposition & $640-/ 759 /-860$ & 8.28 \\
\hline \multirow[t]{6}{*}{3} & 1. Clay minerals dehydration & $40-/ 100 /-230$ & 4.64 & 1. Clay minerals dehydration & $40-/ 91 /-235$ & 4.58 \\
\hline & \multirow{2}{*}{$\begin{array}{l}\text { 2. Organic matter combustion with } \\
\text { overlapping pyrite decomposition }\end{array}$} & $230-/ 341,425 /-620$ & 10.55 & 2. Pyrolysis stage I & $350-/ 460 /-490$ & 4.60 \\
\hline & & $620-/ 755 /-1000$ & 4.98 & 3. Pyrolysis stage II & $490-/ 524 /-633$ & 3.84 \\
\hline & \multirow[t]{3}{*}{ 3. Calcite decomposition } & & & 4. Calcite and pyrite & $633-/ 755 /-848$ & 7.40 \\
\hline & & & & decomposition & $848-1000$ & 1.17 \\
\hline & & & & 5. Muscovite dehydroxylation & & \\
\hline \multirow[t]{6}{*}{4} & 1. Clay minerals dehydration & $40-/ 95 /-250$ & 3.24 & 1. Clay minerals dehydration & $40-/ 94 /-265$ & 4.30 \\
\hline & \multirow{2}{*}{$\begin{array}{l}\text { 2. Organic matter combustion with } \\
\text { overlapping pyrite decomposition }\end{array}$} & $280-/ 434,470 /-620$ & 12.92 & 2. Pyrolysis stage I & $360-/ 450 /-482$ & 3.75 \\
\hline & & $620-/ 773 /-1000$ & 7.91 & 3. Pyrolysis stage II & $482-/ 516 /-650$ & 4.22 \\
\hline & \multirow[t]{3}{*}{ 3. Calcite decomposition } & & & 4. Calcite and pyrite & $675-/ 763 /-825$ & 10.58 \\
\hline & & & & decomposition & $825-1000$ & 1.91 \\
\hline & & & & 5. Muscovite dehydroxylation & & \\
\hline \multirow[t]{4}{*}{5} & 1. Clay minerals dehydration & $40-225$ & 0.55 & 1. Pyrolysis & $454-/ 541 /-633$ & 3.68 \\
\hline & 2. Organic matter combustion & $347-/ 537 /-610$ & 2.95 & 2. Calcite decomposition & $633-/ 725 /-808$ & 4.49 \\
\hline & 3. Calcite decomposition & $610-/ 694 /-875$ & 4.41 & & & \\
\hline & 4. Spinel phases crystallisation & Max. 898 & - & & & \\
\hline \multirow[t]{5}{*}{6} & 1. Clay minerals dehydration & $40-256$ & 0.87 & 1. Clay minerals dehydration & $50-/ 104 /-188$ & 0.52 \\
\hline & 2. Org. matter combustion I & $256-/ 350 /-397$ & 1.20 & 2. Pyrolysis stage I & $316-/ 474 /-498$ & 2.46 \\
\hline & 3. Org. matter combustion II & $397-/ 468 /-526$ & 6.18 & 3. Pyrolysis stage II & $498-/ 535 /-663$ & 4.10 \\
\hline & 4. Org. matter combustion III & $526-/ 543 /-615$ & 3.29 & 4. Clay minerals dehydroxylation & $663-/ 720 /-790$ & 1.62 \\
\hline & 5. Clay minerals dehydroxylation & $710-/ 834 /-933$ & 1.56 & & & \\
\hline \multirow[t]{4}{*}{7} & 1. Clay minerals dehydration & $40-350$ & 0.62 & 1. Clay minerals dehydration & $40-350$ & 2.43 \\
\hline & \multirow{2}{*}{$\begin{array}{l}\text { 2. Organic matter combustion with } \\
\text { overlapping pyrite decomposition }\end{array}$} & $350-/ 493 /-650$ & 8.94 & 2. Pyrolysis & $350-/ 524 /-640$ & 4.45 \\
\hline & & $650-1000$ & 1.67 & 3. Clay minerals dehydroxylation & $640-/ 695 /-790$ & 1.83 \\
\hline & $\begin{array}{l}\text { 3. Clay minerals and muscovite } \\
\text { dehydroxylation }\end{array}$ & & & $\begin{array}{l}\text { and pyrite decomposition } \\
\text { 4. Muscovite dehydroxylation }\end{array}$ & $790-1000$ & 1.34 \\
\hline \multirow[t]{6}{*}{8} & 1. Clay minerals dehydration & $40-257$ & 0.82 & 1. Pyrolysis stage I & $380-/ 468 /-495$ & 1.81 \\
\hline & 2. Org. matter combustion I & $257-/ 355 /-377$ & 0.55 & 2. Pyrolysis stage II & $495-642$ & 2.66 \\
\hline & 3. Org. matter combustion II & $377-/ 397,458 /-524$ & 3.04 & 3. Muscovite dehydroxylation & $642-/ 693 /-789$ & 1.47 \\
\hline & 4. Org. matter combustion III & $524-672$ & 2.21 & & & \\
\hline & 5. Calcite decomposition & $672-/ 784 /-843$ & 1.28 & & & \\
\hline & 6. Clay min. dehydroxylation & $843-/ 893 /-1000$ & 0.55 & & & \\
\hline \multirow[t]{3}{*}{9} & 1. Clay minerals dehydration & $40-350$ & 0.49 & 1. Clay minerals dehydration & $40-400$ & 1.96 \\
\hline & \multirow{2}{*}{$\begin{array}{l}\text { 2. Organic matter combustion with } \\
\text { overlapping pyrite decomposition }\end{array}$} & $350-/ 484 /-650$ & 6.52 & 2. Pyrolysis & $400-/ 526 /-643$ & 3.44 \\
\hline & & $650-1000$ & 1.74 & 3. Clay minerals dehydroxylation & $\begin{array}{c}643-/ 713 /- \\
1000\end{array}$ & 3.23 \\
\hline
\end{tabular}


Table 2 (continued)

\begin{tabular}{|c|c|c|c|c|c|c|}
\hline \multirow[t]{2}{*}{ Sample } & \multicolumn{3}{|l|}{$\begin{array}{l}\text { Procedure I } \\
\text { Oxidising atmosphere }\end{array}$} & \multicolumn{3}{|l|}{$\begin{array}{l}\text { Procedure II } \\
\text { Inert atmosphere }\end{array}$} \\
\hline & Reaction & $\begin{array}{l}\text { Temperature range/ } \\
{ }^{\circ} \mathrm{C}\end{array}$ & $\begin{array}{l}\text { Mass } \\
\text { loss } / \%\end{array}$ & Reaction & $\begin{array}{l}\text { Temperature } \\
\text { range } /{ }^{\circ} \mathrm{C}\end{array}$ & $\begin{array}{l}\text { Mass } \\
\text { loss } / \%\end{array}$ \\
\hline \multirow[t]{3}{*}{10} & 1. Clay minerals dehydration & $40-277$ & 2.41 & 1. Clay minerals dehydration & $40-/ 114 /-205$ & 0.73 \\
\hline & 2. Organic matter combustion & $277-/ 409,508 /-615$ & 16.70 & 2. Pyrolysis stage I & $355-/ 459 /-500$ & 4.11 \\
\hline & 3. Clay minerals dehydroxylation & $615-/ 694 /-875$ & 3.52 & 3. Pyrolysis stage II & $500-/ 535 /-647$ & 1.43 \\
\hline \multirow[t]{4}{*}{11} & 1. Clay minerals dehydration & $40-/ 100 /-250$ & 1.69 & 1. Clay minerals dehydration & $40-250$ & 2.94 \\
\hline & 2. Organic matter combustion & $340-/ 442,514 /-585$ & 11.84 & 2. Pyrolysis stage I & $387-/ 490 /-550$ & 4.09 \\
\hline & \multirow{2}{*}{$\begin{array}{l}\text { 3. Clay minerals (chlorite) } \\
\text { dehydroxylation }\end{array}$} & \multirow[t]{2}{*}{$585-/ 653,850 /-1000$} & \multirow[t]{2}{*}{7.16} & 3. Pyrolysis stage II & $550-/ 584 /-660$ & 3.22 \\
\hline & & & & 4. Clay minerals dehydroxylation & $660-1000$ & 4.24 \\
\hline
\end{tabular}

n.o. determination not possible

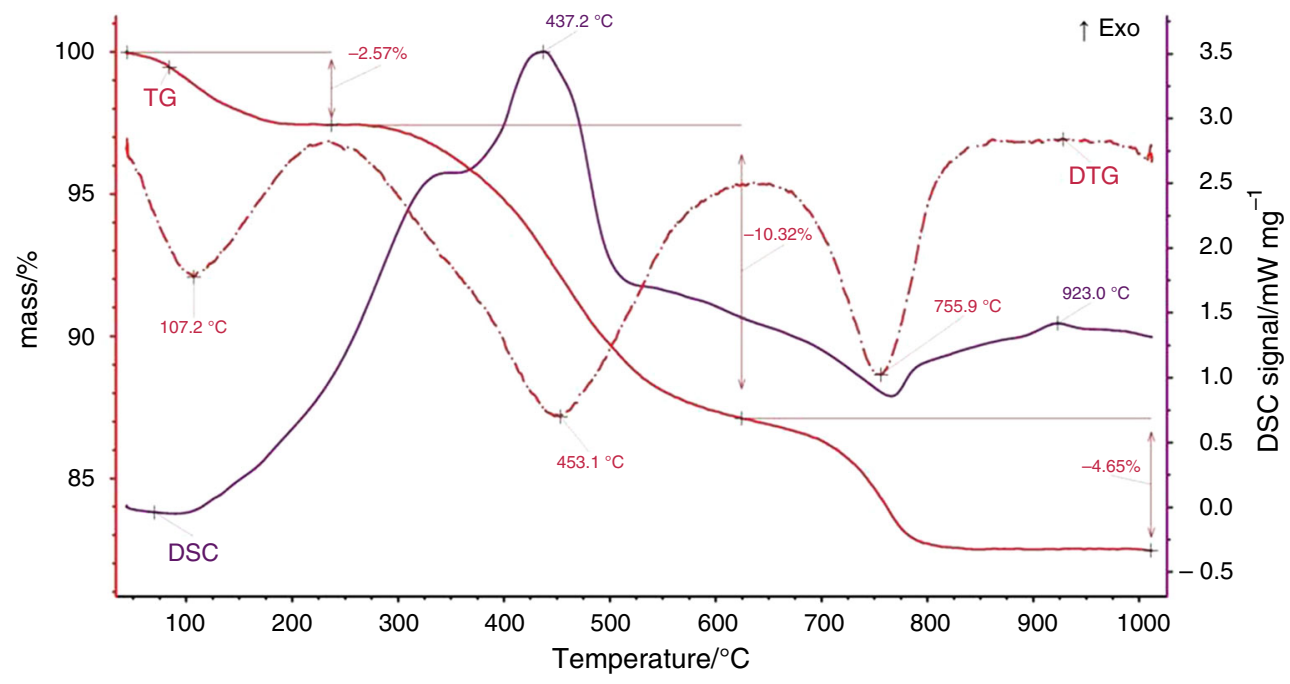

Fig. 1 TG/DTG/DSC pattern of sample 2 (Procedure I)

Fig. 2 TG/DTG/DSC pattern of sample 2 (Procedure II)

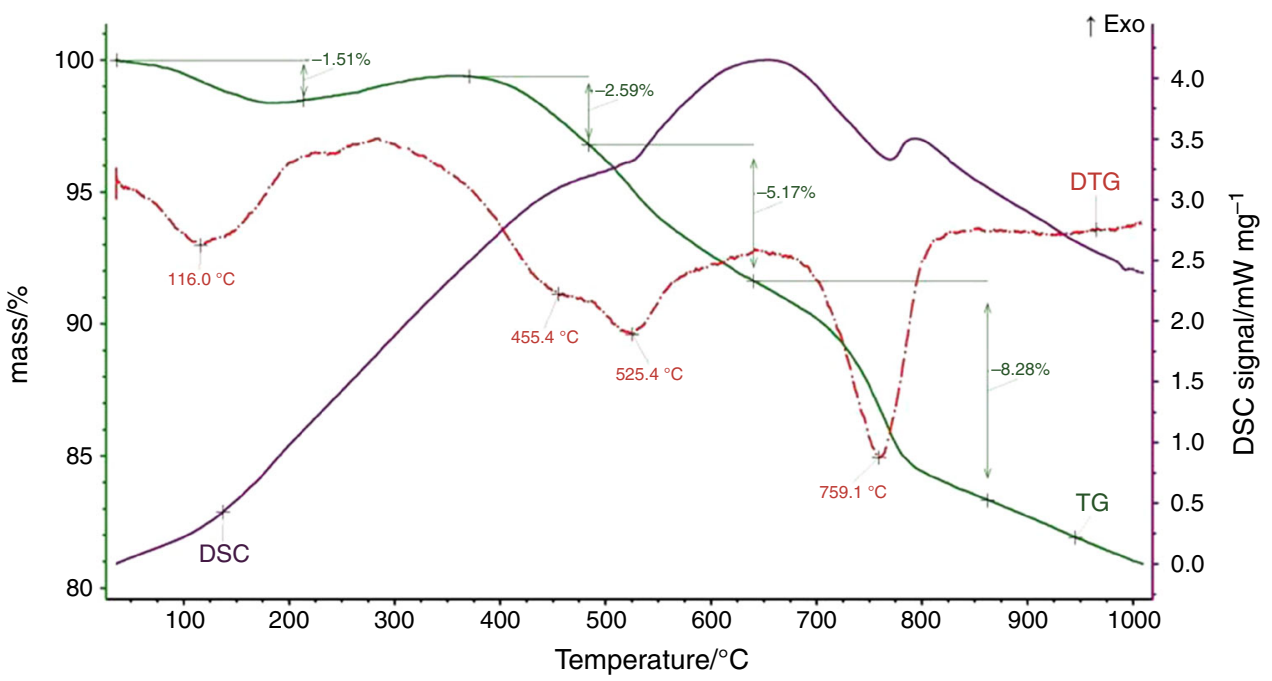


I of the experiment, it can be noticed the mass difference, which is probably connected to overlapping reaction of pyrite disproportion. In the experiment of Procedure II, any effect of spinel phases synthesis is not visible.

The overlapping of the reactions of calcite and pyrite decomposition is also possible in case of samples 3 and 4 . For samples 7 and 9, the endothermic effect of pyrite decomposition is overlapping clay minerals dehydroxylation (Table 2).

\section{Procedure III}

In this procedure, the complex heating programme, close to the Rock-Eval pyrolysis analysis, was implemented. Figure 3 shows TG and DSC curves in a function of time. Temperature curve is drown with dotted line. Due to the use of isothermal intervals in the heating programme, the average heating rate is lower than in procedure II. As a result, the temperature ranges of the detected reactions are usually lower in procedure III. In case of the example sample 2, the maximum rate of calcite decomposition falls into $759{ }^{\circ} \mathrm{C}$ under constant heating regime, and on $751{ }^{\circ} \mathrm{C}$ under interval heating.

As it is visible in Fig. 3, it is easy in this procedure to detect mass changes in each of the heating stages. If we consider sample 2 , the mass losses are as follows: $4.42 \%$ in temperature range $40-300{ }^{\circ} \mathrm{C} ; 6.48 \%$ in range of $300-650{ }^{\circ} \mathrm{C}$, and $5.94 \%$ in range of $650-1050{ }^{\circ} \mathrm{C}$. Due to the decomposition of organic matter, the most interesting is the interval from 300 to $650{ }^{\circ} \mathrm{C}$, which could be compared to $S_{2}$ obtained from Rock-Eval analysis.

\section{Comparison of Rock-Eval and TG analysis}

Marshall et al. [13] indicate the possibility of comparing Rock-Eval pyrolysis results (including $S_{1}$ and $S_{2}$ ) with data obtained from thermogravimetric analysis of separated kerogen, in a range of 300 to $500{ }^{\circ} \mathrm{C}$ for $S_{2}$. They find a significant correlation between $S_{2}$ values obtained by pyrolytic and thermogravimetric methods, as well as a high correlation coefficient between $S_{2}$ from TG and aliphatic carbon in samples.

In case of our examination, the bulk samples were examined by TG analysis; hence, such a high correlation coefficient, as found by Marshall et al. [13], should not be expected. Rock-Eval $S_{2}$ parameter was compared to the mass loss (from Procedure III measurement) during second dynamic heating interval $\left(300-650{ }^{\circ} \mathrm{C}\right)$ (Fig. 4).

A weak correlation was found between Rock-Eval pyrolysis $S_{2}$ and TG mass loss in heating interval $300-650{ }^{\circ} \mathrm{C}\left(R^{2}=0.6843\right)$. The reason is that within the bulk rock sample many reactions occur in a given temperature range that affect the loss of mass. These reactions (under inert atmosphere) include pyrite decomposition, clay minerals dehydroxylation, and the first stage of carbonates decomposition. To examine this relationship, the TG mass loss (within interval $300-650{ }^{\circ} \mathrm{C}$ ) in subsequent

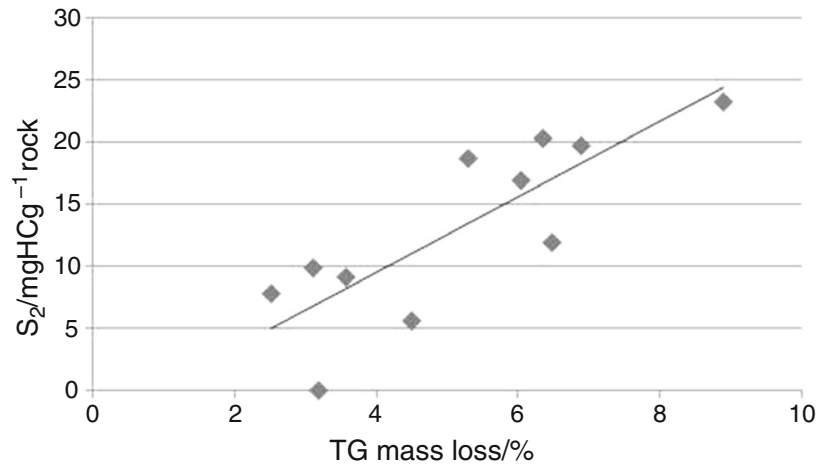

Fig. 4 Plot of TG mass loss in heating interval $300-650{ }^{\circ} \mathrm{C}$ versus Rock-Eval pyrolysis $S_{2}$ parameter
Fig. 3 TG/DSC pattern of sample 2 in a function of time (Procedure III)

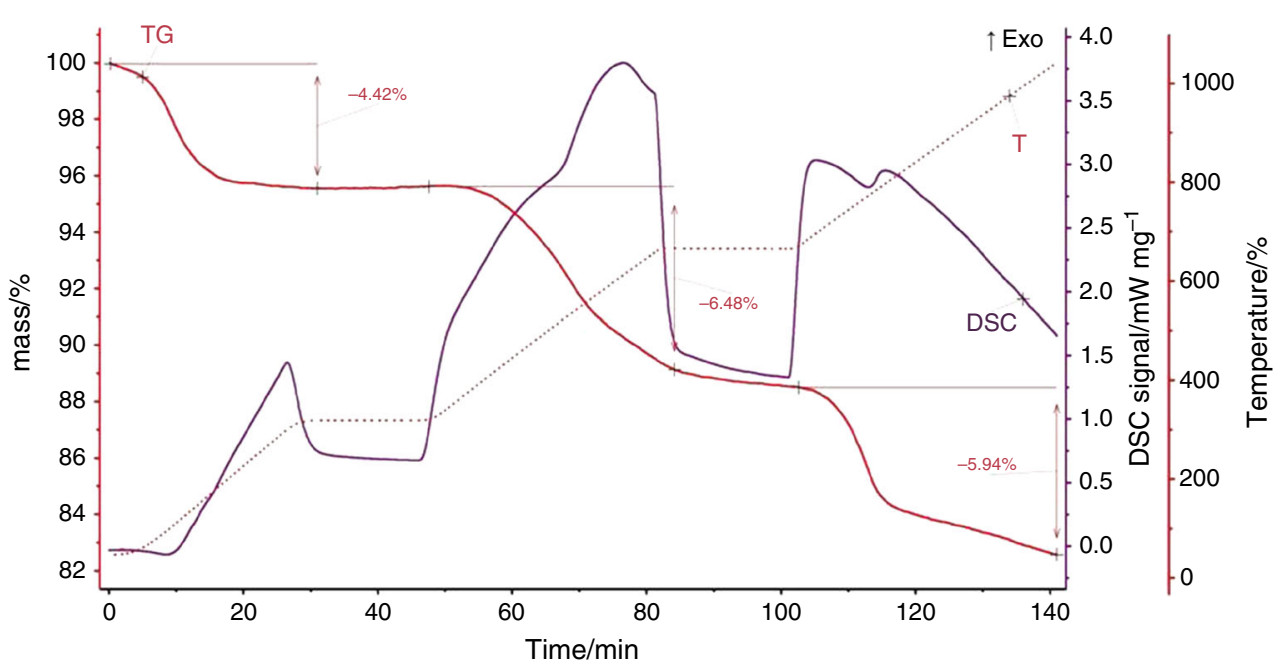


Table 3 TG mass loss in heating interval $300-650{ }^{\circ} \mathrm{C}$ compared to Rock-Eval $S_{2}$ parameter/\%

\begin{tabular}{llllll}
\hline Sample & $\mathrm{TG}_{\mathrm{I}}$ & $\mathrm{TG}_{\mathrm{II}}$ & $\mathrm{TG}_{\mathrm{III}}$ & $S_{2}$ & $\mathrm{TG}_{\mathrm{III}}-S_{2}$ \\
\hline 1 & 11.22 & 7.18 & 6.04 & 1.70 & 4.34 \\
2 & 10.32 & 7.71 & 6.48 & 1.20 & 5.28 \\
3 & 10.61 & 8.29 & 6.36 & 2.02 & 4.34 \\
4 & 13.06 & 8.78 & 8.90 & 2.33 & 6.57 \\
5 & 3.60 & 4.82 & 3.18 & 0.01 & 3.17 \\
6 & 10.03 & 6.43 & 5.30 & 1.86 & 3.44 \\
7 & 8.98 & 5.09 & 3.57 & 0.91 & 2.66 \\
8 & 5.56 & 5.05 & 3.10 & 0.99 & 2.11 \\
9 & 6.57 & 4.15 & 2.52 & 0.79 & 1.73 \\
10 & 18.02 & 8.40 & 6.89 & 1.97 & 4.92 \\
11 & 14.71 & 8.04 & 4.50 & 0.57 & 3.93 \\
\hline
\end{tabular}

$T G_{I}$ Procedure I, $T G_{I I}$ Procedure II, $T G_{I I I}$ Procedure III

analytical procedures (I-III) with $S_{2}$ from pyrolysis is summarized in Table 3. For the corresponding comparison of these data, parameter $S_{2}$ was converted into \%.

TG mass loss under oxidation conditions $\left(\mathrm{TG}_{\mathrm{I}}\right)$ in the temperature range of $300-650{ }^{\circ} \mathrm{C}$ is connected to the organic matter combustion and in some cases to pyrite decomposition. The high value of $\mathrm{TG}_{\mathrm{I}}$ indicates high organic matter content (as in case of samples: 1, 2, 3, 4, 6, 10 ), what is confirmed by high $S_{2}$ value. The mass loss under inert atmosphere differs between the two described above procedures $\left(\mathrm{TG}_{\mathrm{II}}\right.$ and $\left.\mathrm{TG}_{\mathrm{III}}\right)$ in a consequence of different heating programmes. The values of $\mathrm{TG}_{\mathrm{II}}$ are usually higher than $\mathrm{TG}_{\mathrm{III}}$, because of the presence of isothermal intervals in the heating programme in Procedure III. During these intervals, the mass of the sample decreases slightly, but the loss is not measured, as it is visible in Fig. 3, which is the weakness of Procedure III. This procedure is, however, taken into account when comparing the results of thermogravimetric measurement and Rock-Eval analysis, as it corresponds to the RockEval heating regime. $S_{2}$ value is here (Table 3) expressed as a percentage corresponding to the $\mathrm{HC}$ present in the rock. The difference between $S_{2}[\%]$ and $\mathrm{TG}_{\mathrm{III}}$ is the decomposition of other compounds in the sample (e.g. pyrite, calcite, chlorite).

\section{Fractional composition of hydrocarbons obtained from Py-GC pyrolysis}

For representative samples from particular stratigraphic levels, $\mathrm{Py}-\mathrm{GC}$ analysis was performed in five temperature ranges in order to determine qualitatively the pyrolysis products, which will allow predicting the type of hydrocarbons generated in the process of thermal evolution of
Table 4 Results of Py-GC analyses for Menilite and lower Paleozoic shales showing the fractional composition of pyrolysis products

\begin{tabular}{|c|c|c|c|c|c|}
\hline \multirow{2}{*}{$\begin{array}{l}\text { Fraction } \\
\text { Pyrolysis temp } /{ }^{\circ} \mathrm{C}\end{array}$} & \multicolumn{5}{|c|}{ Share of fraction/\% } \\
\hline & 300 & 400 & 500 & 650 & 1000 \\
\hline \multicolumn{6}{|c|}{ Menilite shale from Silesian unit (sample 2) } \\
\hline $\mathrm{C}_{1}-\mathrm{C}_{9}$ & 0.00 & 21.79 & 30.02 & 76.35 & 87.68 \\
\hline $\mathrm{C}_{9}-\mathrm{C}_{15}$ & 12.68 & 27.56 & 36.40 & 11.61 & 0.10 \\
\hline $\mathrm{C}_{15+}$ & 87.32 & 50.65 & 33.58 & 12.03 & 12.22 \\
\hline \multicolumn{6}{|c|}{ Menilite black shale from Magura unit (sample 4) } \\
\hline $\mathrm{C}_{1}-\mathrm{C}_{9}$ & 0.00 & 11.33 & 31.30 & 80.34 & 91.52 \\
\hline $\mathrm{C}_{9}-\mathrm{C}_{15}$ & 1.84 & 13.52 & 34.01 & 13.00 & 0.50 \\
\hline $\mathrm{C}_{15+}$ & 98.16 & 75.16 & 34.68 & 6.66 & 7.98 \\
\hline \multicolumn{6}{|c|}{ Lower Silurian black shale (sample 6) } \\
\hline $\mathrm{C}_{1}-\mathrm{C}_{9}$ & 0.46 & 19.06 & 54.61 & 90.32 & 94.35 \\
\hline $\mathrm{C}_{9}-\mathrm{C}_{15}$ & 54.98 & 38.01 & 30.75 & 7.73 & 0.00 \\
\hline $\mathrm{C}_{15+}$ & 44.56 & 42.93 & 14.64 & 1.95 & 5.65 \\
\hline \multicolumn{6}{|c|}{ Ordovician shale (sample 8) } \\
\hline $\mathrm{C}_{1}-\mathrm{C}_{9}$ & 1.85 & 3.74 & 35.95 & 83.25 & 96.98 \\
\hline $\mathrm{C}_{9}-\mathrm{C}_{15}$ & 25.66 & 36.98 & 34.83 & 12.86 & 0.00 \\
\hline $\mathrm{C}_{15+}$ & 72.49 & 59.28 & 29.22 & 3.89 & 3.02 \\
\hline \multicolumn{6}{|c|}{ Upper Cambrian grey shale (sample 10) } \\
\hline $\mathrm{C}_{1}-\mathrm{C}_{9}$ & 0.00 & 83.27 & 67.90 & 98.92 & 97.89 \\
\hline $\mathrm{C}_{9}-\mathrm{C}_{15}$ & 16.54 & 10.11 & 25.11 & 0.00 & 0.00 \\
\hline $\mathrm{C}_{15+}$ & 83.46 & 6.62 & 6.99 & 1.08 & 2.11 \\
\hline
\end{tabular}

source rocks. The fractional composition also allows to distinguish gas-prone versus oil-prone types of generation potential. Among the analysed rock samples, the Menilite samples are clearly distinguished by a high content of the $\mathrm{C}_{15+}$ fraction, especially in the temperature range of $300-500{ }^{\circ} \mathrm{C}$ (Table 4). Above $500{ }^{\circ} \mathrm{C}$, the dominance of light hydrocarbons is observed, as in all other samples. In the Lower Silurian shale (sample 6) in the $300-400{ }^{\circ} \mathrm{C}$ range, the largest share is $\mathrm{C}_{15+}$, while in the Upper Cambrian formations, the $\mathrm{C}_{15+}$ fraction is formed mainly in the range up to $300{ }^{\circ} \mathrm{C}$. At higher temperatures, the predominant products are light hydrocarbons.

The above observations indicate a high qualitative diversity of the generation potential of individual shale formations. The variability tendency is analogous to the variation of the HI parameter in the Rock-Eval analysis. This means that Menilite shales should be classified as source rocks with high oil generation potential. Similarly, the Lower Silurian and Ordovician shales are characterized by high oil-producing potential with a lower content of mineral matter. Cambrian samples are distinguished by both Py-GC and Rock-Eval analysis results, indicating their gas-prone character with a lower HI. 


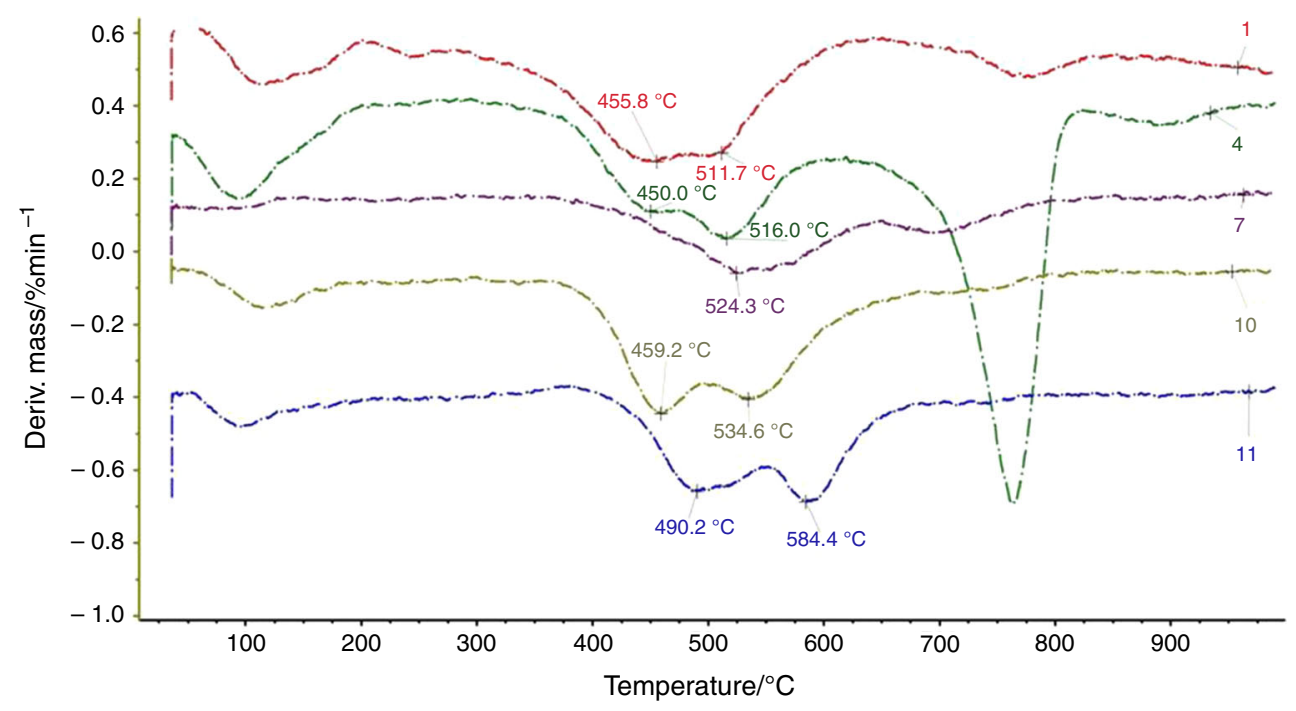

Fig. 5 DTG curves for some selected samples (Procedure II). The vertical axis scale corresponds to sample 10

\section{Discussion}

Many authors note that the presence of mineral matter in oil shale influences significantly the pyrolysis reaction [18]. In case of gas shale, this effect is believed to be even more important, as gas shale contains more inorganic material than oil shale. The minerals in gas shale are carbonates, silicates and sulphides (mainly pyrite). The minerals detected in the examined shale samples represent clay minerals (including chlorites), calcite, muscovite and pyrite. Significant correlation between lithology and organic content in the samples was not stated.

From the viewpoint of decomposition of organic matter under inert gas conditions, the most interesting is the temperature range from 280 to about $600{ }^{\circ} \mathrm{C}$, where the peaks reflect the release of gaseous components in the sample by pyrolysis process. The summary of the DTG curves for the selected samples (Fig. 5-reducing the number of samples in this figure was to increase the legibility of the diagram) allows to compare the range of temperatures in which the most intense changes (losses) occur during the pyrolysis reaction. According to Durand [19], a thermogravimetric analysis in an inert atmosphere allows the determination of three stages of organic matter decomposition. The first stage, to about $350{ }^{\circ} \mathrm{C}$, is associated with the release of moisture and $\mathrm{CO}_{2}$ from the sample. In the second stage, up to about $500{ }^{\circ} \mathrm{C}$, hydrocarbons are released. Above this temperature is the third step; the structural reconstruction of organic compounds is involved, without a significant loss of mass. The mass loss ratio during the first two steps allows the classification of kerogen. The larger loss of mass in the first stage indicates the oxygen-rich kerogen belonging to type III. Larger mass loss in the second stage of pyrolysis indicates a high hydrogen content, which is characteristic for kerogen type II.

The above-mentioned effects are clear in the case of the analysis of the separated kerogen. For rocks with dispersed organic matter, as in the present study, the first peaks are not recorded. The second effect, as the strongest, is visible on the DSC curves and is also prominently displayed on the DTG curves due to the significant loss of mass. As it can be seen in Fig. 5, the maximum of the reaction of pyrolysis ranges from 450 to $584{ }^{\circ} \mathrm{C}$, depending on the degree of maturity of the organic matter. The increase in pyrolysis peak temperature indicates the thermal maturity of the kerogen in the sample [20]. Therefore, sample 11 is of the highest degree of maturity. For most of the samples the pyrolysis reaction proceeds in two stages (see Table 2), whereas pyrolysis for sample 7 and 9 takes place in one step.

In case of Cambrian samples, TG/DTG results show that the first pyrolysis stage (at the lower temperature range) is connected to the higher mass loss (Table 2). This observation is consistent with $\mathrm{Py}-\mathrm{GC}$ data, indicating that the main products of pyrolysis of Cambrian rocks at the $400-650{ }^{\circ} \mathrm{C}$ range are light hydrocarbons of the $\mathrm{C}_{1}-\mathrm{C}_{9}$ fraction (Table 4). Also from $\mathrm{Py}-\mathrm{GC}$ results, it is visible that the highest amount of light hydrocarbons $\left(\mathrm{C}_{1}-\mathrm{C}_{9}\right)$ was released in the range over $500{ }^{\circ} \mathrm{C}$ for both Menilite shales, as well as Silurian and Ordovician rocks. These observations indicate the distinct character of Cambrian rocks.

\section{Conclusions}

Thermogravimetric analysis (TG/DTG), coupled with DSC measurement, is a powerful device, complementary to Rock-Eval analysis, providing quantitative information on 
the organic matter present in the sample. To obtain valuable and repeatable results, the precise definition of the experiment conditions is needed. TG/DTG/DSC analysis enables detection of thermoreactive minerals in the samples, including clay minerals, carbonates (e.g. calcite), muscovite and sulphates (e.g. pyrite).

Based on the Rock-Eval analysis results, kerogen in samples can be classified as type II. Additional information on the quality of pyrolysis products was obtained from the Py-GC analysis. Thanks to the combination of the all three implemented pyrolytic techniques, the quality of the generation potential of the source rocks can be evaluated in details.

In some samples the oxidation and pyrolysis of organic matter occur in two stages, what is the evidence of the complex nature of the organic substance. The maximum of pyrolysis reaction is detected by TG/DTG measurement in the range of temperature from 450 to $580{ }^{\circ} \mathrm{C}$, depending on the maturity of organic matter. The maturity level increases with the rock stratigraphic position.

The proportions of loss in mass observed in respective stages of pyrolysis in course of TG/DTG experiment are in correspondence with the observations of the released fractions in the Py-GC analysis.

The Carpathian Menilite shales could be classified as source rocks with high oil generation potential. Also, the Lower Silurian and Ordovician shales are characterized by high oil-producing potential with a lower content of mineral matter. Cambrian rocks show a different character, and gas-prone generation potential.

Acknowledgements This study was supported by the National Centre for Research and Development (Poland) in frames of Blue Gas Project No. BG1/MWSSSG/13-methodology to determine sweet spots based on geochemical, petrophysical and geomechanical properties in connection with correlation of laboratory tests with well logs and generation model 3D-DK-0601-6/13.

Open Access This article is distributed under the terms of the Creative Commons Attribution 4.0 International License (http://creative commons.org/licenses/by/4.0/), which permits unrestricted use, distribution, and reproduction in any medium, provided you give appropriate credit to the original author(s) and the source, provide a link to the Creative Commons license, and indicate if changes were made.

\section{References}

1. Nuñez-Betelu L, Baceta JI. Basics and application of Rock-Eval/ TOC pyrolysis: an example from the uppermost Paleocene/ lowermost Eocene in the Basque Basin Western Pyrenees. Ciencias Nurales Natur Zientziak. 1994;46:43-62.

2. Matyasik I, Słoczyński T. Niekonwencjonalne złoża gazu—shale gas. Nafta Gaz. 2010;66:167-77.

3. Peters KE. Guidelines for evaluating petroleum source rock using programmed pyrolysis. AAPG Bull. 1986;70:318-29.

4. Cebulak S, Langier-Kuźniarowa A. Application of oxyreactive thermal analysis to the examination of organic matter associated with rocks. J Therm Anal. 1997;50:175-90.

5. Wesołowski M. Thermal analysis of petroleum products. Thermochim Acta. 1981;46:21-45.

6. Warne SStJ, Dubrawski JV. Applications of DTA and DSC to coal and oil shale evaluation. J Therm Anal. 1989;35:219-42.

7. Cronauer DC, Snyder RW, Painter PC. Characterization of oil shale by FTIR spectroscopy. In: Abstracts of papers of the American Chemical Society, Los Vegas, vol. 27; 1982, p. 122-130.

8. Ballice L, Yüksel M, Saglam M, Schulz H, Hanoglu C. Application of infrared spectroscopy to the classification of kerogen types and the thermogravimetrically derived pyrolysis kinetic of oil shales. Fuel. 1995;74:1618-23.

9. Kok MV. Thermal investigation of Seyitomer oil shale. Thermochim Acta. 2001;369:149-55.

10. Fan C, Yan J, Huang Y, Han X, Jiang X. XRD and TG-FTIR study of the effect of mineral matrix on the pyrolysis and combustion of organic matter in shale char. Fuel. 2015;139:502-10.

11. Skala D, Korca S, Vitorović D, Neumann HJ. Determination of kerogen type by using DSC ad TG analysis. J Therm Anal. 1997;49:745-53.

12. Labus M. Thermal methods implementation in analysis of finegrained rocks containing organic matter. $\mathrm{J}$ Therm Anal Calorim. 2017;129:965-73.

13. Marshall CP, Kannangara GSK, Wilson MA, Guerbois JP, Hartung-Kagi B, Hart G. Potential of thermogravimetric analysis coupled with mass spectrometry for the evaluation of kerogen in source rocks. Chem Geol. 2002;184:185-94.

14. Liu QQ, Han XX, Li QY, Huang YR, Jiang XM. TG-DSC analysis of pyrolysis process of two Chinese oil shales. J Therm Anal Calorim. 2014;116:511-7.

15. Peters KE, Cassa MR. Applied source rock geochemistry. In: Magoon LB, Dow WG, editors. The petroleum system-from source to trap, vol. 60. AAPG Memoir; 1994, p. 93-120.

16. Földvári M. Handbook of thermogravimetric system of minerals and its use in geological practice. In: Occasional papers of the Geological Institute of Hungary, Budapest, vol. 213; 2011, p. 180.

17. Yariv S. Differential thermal analysis (DTA) of organo-clay complexes. In: Smykatz-Kloss W, Warne SSJ, editors. Thermal analysis in the geosciences, vol. 38., Lecture notes in earth sciencesBerlin: Springer; 1991. p. 328-51.

18. Yan J, Jiang X, Han X, Liu J. A TG-FTIR investigation to the catalytic effect of mineral matrix in oil shale on the pyrolysis and combustion of kerogen. Fuel. 2013;104:307-17.

19. Durand B. Kerogen. Insoluble organic matter from sedimentary rocks. Paris: Editions Technip; 1980.

20. Schmidt CM, Heide K. Thermal analysis of hydrocarbons in Paleozoic black shales. J Therm Anal Calorim. 2001;64:1297-302. 